\section{Quantification of Carbon Assimilation of Plants in Simulated and In Situ Interiorscapes}

\author{
Svoboda V. Pennisi ${ }^{1}$ \\ Department of Horticulture, 1109 Experiment Street, University of Georgia \\ Griffin Campus, Griffin, GA 30223
}

\author{
Marc W. van Iersel \\ Department of Horticulture, The University of Georgia, 1111 Plant Sciences \\ Building, The University of Georgia, Athens, GA 30602-7273
}

Additional index words. carbon footprint, carbon sequestration, foliage plants

\begin{abstract}
Interiorscape plants have many documented benefits, but their potential for carbon sequestration is not clear. This study was undertaken to quantify the amount of carbon assimilation under growth chamber conditions designed to mimic the photosynthetic photon flux (PPF) levels and temperatures of typical indoor environments and to quantify the amount of carbon assimilation in situ in a representative interiorscape composed of a variety of plant species and sizes. Quantitative data were obtained in 1) growth chambers with a typical range of $P P F$ levels encountered indoors $(\approx 10,20$, and $\left.30 \mu \mathrm{mol} \cdot \mathrm{m}^{-2} \cdot \mathrm{s}^{-1}\right)$; and 2 ) in situ conditions in an interiorscape. Under growth chamber conditions, most species exhibited positive dry mass accumulation and carbon sequestration but Sanseveria and Dracaena 'Janet Craig' exhibited consistent dry mass loss throughout the 10 weeks under simulated conditions. Carbon content was lower in herbaceous species (e.g., Scindapsus aureus, $\mathbf{3 8 \%}$ of dry mass) compared with woody ones (e.g., Ficus benjamina, 43\%). PPF-saturated net photosynthetic rates of plants were low, ranging from 3.4 to $7.0 \mu \mathrm{mol} \cdot \mathrm{m}^{-2} \cdot \mathrm{s}^{-1}$, whereas their light compensation points ranged from 8 to $78 \mu \mathrm{mol} \cdot \mathrm{m}^{-2} \cdot \mathrm{s}^{-1}$. In situ, plants exhibited varying dry mass gain, largely dependent on size. In general, a large plant and/or species with a higher amount of woody tissue in their above- or belowground organs (e.g., $4.6 \mathrm{~m}$ high arboreal plant) sequestered more carbon than small and/or herbaceous species. This study is the first to provide quantitative data of carbon sequestration in interiorscape environments.
\end{abstract}

Reduction of the "carbon footprint," increase in the energy efficiency of a building, and other environmentally friendly initiatives have gained considerable public and industry recognition through the Leadership in Energy and Environmental Design certification system administered by the U.S. Green Building Council (USGBC, 2011). Within this system, credits are given for the use of indoor plants because of their phytoremediation quality [removal of harmful volatile organic compounds (Yang et al., 2009)] and psychological benefits (Bringslimark et al., 2007; Lohr

Received for publication 6 Sept. 2011. Accepted for publication 19 Oct. 2011.

We thank Orville Lindstrom and Carol Robacker for review of the manuscript and constructive criticism and Jerry Davis for assistance with the statistical analyses. We thank the following organization and companies: National Foliage Foundation for providing grant funds, Foliage Design Systems Inc. for allowing access to their in situ interiorscape account and assistance in collecting plant materials, and Heart of Florida Inc. for donations of plant materials. We thank Jonathan Frantz (USDA-ARS Application Technology Research Unit, Toledo, $\mathrm{OH}$ ) for performing plant tissue analysis.

${ }^{1}$ To whom reprint requests should be addressed; e-mailbpennisi@uga.edu. et al., 1996). There appears to be no published research on the aspect of indoor air quality: the impact of plants on removal of carbon dioxide from indoor environments. The principal question is whether carbon dioxide removal by indoor plants is of sufficient magnitude to substantiate claims for a significant impact on indoor air quality.

Photosynthetic activity results in the uptake of $\mathrm{CO}_{2}$ from the indoor environment because the photoassimilates are used for new growth and maintenance of existing tissues and organs. Because $P P F$ is the driving force behind photosynthesis, generally more photoassimilates are produced as the $P P F$ level increases. Indoor environments typically have low $P P F$ levels, making $P P F$ the most limiting factor for photosynthesis. The $P P F$ levels in typical commercial interiorscape installations range from more than $40 \mu \mathrm{mol} \cdot \mathrm{m}^{-2} \cdot \mathrm{s}^{-1}$ (rated as a "good" level by interiorscapers), 35 to $30 \mu \mathrm{mol} \cdot \mathrm{m}^{-2} \cdot \mathrm{s}^{-1}$ ("medium" $P P F$ ), or 25 to $15 \mu \mathrm{mol} \cdot \mathrm{m}^{-2} \cdot \mathrm{s}^{-1}$ ("low" PPF) (Manaker, 1981). Under such conditions, plants have variable photosynthetic rates, mainly depending on the ambient PPF levels.

Although photosynthesis is the basic physiological process underlying carbon sequestration, the total amount of carbon sequestered by plants cannot be determined directly from leaf photosynthesis measurements, because leaf measurements do not integrate the whole plant, do not take into account diurnal variations in photosynthesis, and do not account for nighttime respiration (van Iersel and Bugbee, 2000). A more reliable way to determine carbon sequestration is to measure the increase in the total amount of carbon present in the plants. Such data would be valuable both under simulated conditions and in interiorscapes, because there is a lack of quantitative data on plant performance in situ. Our goal was to collect quantitative information that can be used to help predict the magnitude of carbon sequestration by

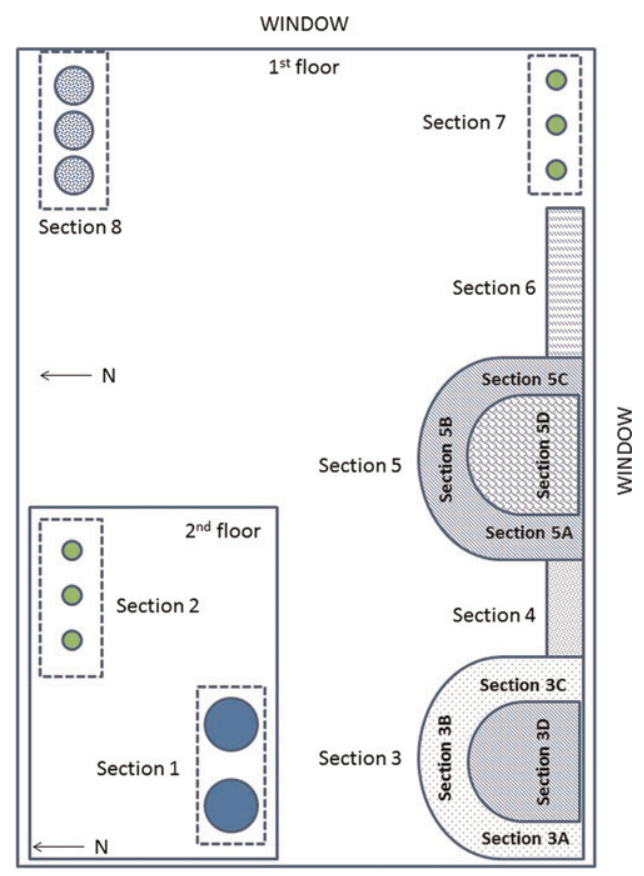

Fig. 1. Diagrammatic representation of in situ interiorscape planting. 
plants in interiorscapes. The specific objectives of this study were to: 1) quantify the photosynthetic activity and carbon sequestration of common interiorscape plants under simulated environments, replicating typical interiorscape conditions; and 2) quantify the amount of carbon assimilation in situ in a commercial interiorscape composed of a variety of plant species and sizes.

\section{Materials and Methods}

\section{Simulated environment}

Plant material. The study extended over a period of 16 months, from Feb. 2009 to June 2010 , to accommodate the number of species and cultivars used. Consecutive shipments of finished plant material (Spathiphyllum 'Sweet Chico' Aglaonema spp., Sanseveria trifasciata 'Hahnii', Chamaedorea elegans, Dracaena marginata, Dracaena godseffiana 'Florida Beauty', Dracaena deremensis 'Lemon Lime', and Dracaena deremensis 'Janet Craig') were obtained from a wholesale producer in Florida. All of these species were grown in round, $10-\mathrm{cm}$ diameter pots, whereas Spathiphyllum was also grown in $15-\mathrm{cm}$ diameter pots. Ctenanthe oppenheimiana, Ficus repens, Hedera helix, Scindapsus aureus, Philodendron scandens, and Dizygotheca elegantissima were clonal material obtained from plants maintained at the University of Georgia greenhouse and rooted under mist. Ficus benjamina was also obtained from cuttings of plants grown inhouse. These cuttings were grown for different lengths of time, referred hereto as $F$. benjamina "immature" and $F$. benjamina "mature," the latter for 8 weeks longer to allow more woody growth to occur. Pachira aquatica was shipped as unrooted tip cuttings from a commercial supplier and was subsequently rooted under mist in a greenhouse. All clonal material was rooted in $10-\mathrm{cm}$ diameter pots, the same size as the shipped finished plants.

Regardless of the origin of the plant material (shipped finished or grown in-house), plants were placed in a double-polyethylene Quonset-style greenhouse for acclimatization under $\approx 100 \mu \mathrm{mol} \cdot \mathrm{m}^{-2} \cdot \mathrm{s}^{-1}$. The light level was measured at $1400 \mathrm{HR}$ under sunny conditions using an LI-190 quantum sensor connected to a handheld LI-250A light meter (Li-COR Biosciences, Lincoln, NE) for a period of 6 weeks. A double layer of aluminum-clad shadecloth was placed over each of the ebband-flow benches on which the plants were grown. The temperature control in the greenhouse was set at $21{ }^{\circ} \mathrm{C}$ day $/ 18{ }^{\circ} \mathrm{C}$ night (Wadsworth Systems, Arvada, CO). Plants were grown on ebb-and-flow benches $(1.2 \times$ $2.4 \mathrm{~m}^{2}$; Midwest GroMaster, St. Charles, IL). Fertilizer solutions were stored in plastic barrels $(210 \mathrm{~L})$ and pumped into the watertight trays of the ebb-and-flow system using submersible pumps (NK-2; Little Giant, Oklahoma City, OK). Fertigation was administered once per week at the rate of 75 ppm nitrogen $(24 \mathrm{~N}-8 \mathrm{P}-16 \mathrm{~K})$ in accordance with a recommended fertilization regime for

Table 1. Dry mass, growth, and carbon sequestration of foliage species and cultivars as affected by $P P F$ level. $^{z}$

\begin{tabular}{|c|c|c|c|c|c|}
\hline Species & $\begin{array}{c}P P F \\
\left(\mu \mathrm{mol} \cdot \mathrm{m}^{-2} \cdot \mathrm{s}^{-1}\right)\end{array}$ & $\begin{array}{c}\text { Final } \\
\text { biomass } \\
(\mathrm{g})\end{array}$ & $\begin{array}{l}\text { Biomass } \\
\text { increase } \\
(\mathrm{g})\end{array}$ & $\begin{array}{c}\text { Relative } \\
\text { growth rate } \\
\left(\mathrm{mg} \cdot \mathrm{g}^{-1} \cdot \mathrm{d}^{-1}\right)\end{array}$ & $\begin{array}{c}\text { Carbon } \\
\text { sequestered } \\
(\mathrm{g})\end{array}$ \\
\hline \multirow{4}{*}{ Aglaonema spp. } & $\mathrm{H}$ & 35.0 & 19.0 & 11.1 & 7.5 \\
\hline & M & 28.6 & 12.6 & 8.4 & 5.0 \\
\hline & $\mathrm{L}$ & 21.1 & 5.1 & 4.6 & 1.9 \\
\hline & Significance & $* *$ & $*$ & $* * *$ & $* *$ \\
\hline \multirow[t]{4}{*}{ Chamaedorea elegans } & $\mathrm{H}$ & 27.7 & 9.5 & 5.7 & 4.0 \\
\hline & M & 24.4 & 6.3 & 3.8 & 2.6 \\
\hline & $\mathrm{L}$ & 22.7 & 4.6 & 2.9 & 1.9 \\
\hline & Significance & $*$ & $*$ & $*$ & $*$ \\
\hline \multirow[t]{4}{*}{ Ctenanthe oppenheimiana } & $\mathrm{H}$ & 33.3 & 17.8 & 9.0 & 7.3 \\
\hline & M & 33.1 & 17.6 & 9.2 & 7.2 \\
\hline & $\mathrm{L}$ & 27.3 & 11.8 & 6.6 & 4.8 \\
\hline & Significance & NS & $*$ & NS & NS \\
\hline \multirow{4}{*}{ Dizygotheca elegantissima } & $\mathrm{H}$ & 8.9 & 4.2 & 8.8 & 1.9 \\
\hline & M & 7.5 & 2.8 & 6.3 & 1.2 \\
\hline & $\mathrm{L}$ & 6.0 & 1.3 & 3.3 & 0.5 \\
\hline & Significance & $* *$ & $* *$ & $* *$ & $* *$ \\
\hline \multirow{2}{*}{ Dracaena godseffiana } & $\mathrm{H}$ & 11.7 & 5.5 & 8.4 & 2.3 \\
\hline & M & 11.7 & 5.5 & 8.6 & 2.3 \\
\hline \multirow{2}{*}{ 'Florida Beauty' } & $\mathrm{L}$ & 8.5 & 2.3 & 3.8 & 0.9 \\
\hline & Significance & $*$ & $*$ & $*$ & $*$ \\
\hline \multirow{4}{*}{ Dracaena deremensis 'Lemon Lime' } & $\mathrm{H}$ & 13.5 & 0.7 & $-^{x}$ & 0.3 \\
\hline & M & 12.2 & $-0.6^{\mathrm{y}}$ & - & -0.2 \\
\hline & $\mathrm{L}$ & 11.0 & -1.7 & - & -0.7 \\
\hline & Significance & $* *$ & $* *$ & - & $* *$ \\
\hline \multirow[t]{4}{*}{ Dracaena deremensis 'Janet Craig' } & $\mathrm{H}$ & 21.5 & -1.7 & - & -0.7 \\
\hline & M & 20.5 & -2.7 & - & -1.1 \\
\hline & $\mathrm{L}$ & 18.2 & -4.9 & - & -1.9 \\
\hline & Significance & $*$ & $*$ & - & $*$ \\
\hline \multirow[t]{4}{*}{ Dracaena marginata } & $\mathrm{H}$ & 30.0 & 4.0 & - & 1.3 \\
\hline & M & 23.4 & 0.8 & - & 0.6 \\
\hline & $\mathrm{L}$ & 21.5 & 1.0 & - & 0.2 \\
\hline & Significance & $*$ & $*$ & - & $*$ \\
\hline \multirow[t]{4}{*}{ Ficus benjamina immature } & $\mathrm{H}$ & 5.3 & 3.0 & 11.5 & 1.3 \\
\hline & M & 5.3 & 3.0 & 11.0 & 1.3 \\
\hline & $\mathrm{L}$ & 4.3 & 2.0 & 8.6 & 0.8 \\
\hline & Significance & NS & NS & NS & NS \\
\hline \multirow[t]{4}{*}{ Ficus benjamina mature } & $\mathrm{H}$ & 11.0 & 4.3 & 8.0 & 1.9 \\
\hline & M & 9.7 & 3.0 & 6.1 & 1.3 \\
\hline & $\mathrm{L}$ & 8.3 & 1.6 & 3.9 & 0.7 \\
\hline & Significance & $* * *$ & $* * *$ & $* * *$ & $* * *$ \\
\hline \multirow[t]{4}{*}{ Ficus repens } & $\mathrm{H}$ & 4.1 & 1.3 & 5.3 & 0.5 \\
\hline & M & 4.1 & 1.3 & 5.2 & 0.5 \\
\hline & $\mathrm{L}$ & 4.1 & 1.3 & 4.9 & 0.5 \\
\hline & Significance & NS & NS & NS & NS \\
\hline \multirow[t]{4}{*}{ Hedera helix } & $\mathrm{H}$ & 2.2 & 1.4 & 2.1 & 0.6 \\
\hline & M & 2.1 & 1.3 & 2.0 & 0.5 \\
\hline & $\mathrm{L}$ & 1.7 & 0.9 & 1.0 & 0.4 \\
\hline & Significance & NS & $*$ & $*$ & NS \\
\hline \multirow[t]{4}{*}{ Pachira aquatica } & $\mathrm{H}$ & 42.6 & 33.1 & 21.2 & 13.8 \\
\hline & M & 34.6 & 24.9 & 17.8 & 10.4 \\
\hline & $\mathrm{L}$ & 27.6 & 18.0 & 14.1 & 7.5 \\
\hline & Significance & $* *$ & $* *$ & $* * *$ & $* *$ \\
\hline Philodendron scandens & $\mathrm{H}$ & 6.4 & 3.3 & 9.0 & 1.3 \\
\hline & M & 5.3 & 2.2 & 6.1 & 0.9 \\
\hline & $\mathrm{L}$ & 4.9 & 1.7 & 4.6 & 0.7 \\
\hline & Significance & $*$ & $*$ & $*$ & $*$ \\
\hline Sansevieria trifasciata 'Hahnii' & $\mathrm{H}$ & 24.7 & -4.3 & - & -1.6 \\
\hline & M & 21.6 & -7.4 & - & -2.8 \\
\hline & $\mathrm{L}$ & 18.7 & -10.3 & - & -3.9 \\
\hline & Significance & $* * *$ & $* * *$ & & $* * *$ \\
\hline Scindapsus aureus & $\mathrm{H}$ & 9.6 & 8.2 & 21.0 & 3.2 \\
\hline & M & 7.2 & 5.8 & 17.2 & 2.3 \\
\hline & $\mathrm{L}$ & 6.7 & 5.3 & 16.1 & 2.0 \\
\hline & Significance & $* *$ & $* *$ & $* *$ & $* *$ \\
\hline
\end{tabular}

(Continued on next page)

acclimatized indoor plants (Conover and Poole, 1981). Media fertility levels were monitored biweekly on a random sample of 12 to 24 plants using the pour-through method (Yeager et al., 1997). Distilled water (50 mL) was poured into each pot and allowed to drain; leachate was collected and $\mathrm{pH}$ and electrical conductivity (EC) were analyzed (Agrimeter 
Table 1. (Continued) Dry mass, growth, and carbon sequestration of foliage species and cultivars as affected by $P P F$ level. ${ }^{z}$

\begin{tabular}{|c|c|c|c|c|c|}
\hline Species & $\begin{array}{c}P P F \\
\left(\mu \mathrm{mol} \cdot \mathrm{m}^{-2} \cdot \mathrm{s}^{-1}\right)\end{array}$ & $\begin{array}{c}\text { Final } \\
\text { biomass } \\
(\mathrm{g})\end{array}$ & $\begin{array}{c}\text { Biomass } \\
\text { increase } \\
(\mathrm{g})\end{array}$ & $\begin{array}{c}\text { Relative } \\
\text { growth rate } \\
\left(\mathrm{mg} \cdot \mathrm{g}^{-1} \cdot \mathrm{d}^{-1}\right)\end{array}$ & $\begin{array}{c}\text { Carbon } \\
\text { sequestered } \\
(\mathrm{g})\end{array}$ \\
\hline \multirow[t]{4}{*}{ Spathiphyllum 'Sweet Chico' (10 cm) } & $\mathrm{H}$ & 17.8 & 4.9 & 5.3 & 2.1 \\
\hline & M & 14.6 & 1.7 & 2.7 & 0.7 \\
\hline & $\mathrm{L}$ & 14.4 & 1.5 & 2.4 & 0.6 \\
\hline & Significance & $* *$ & $* *$ & $* * *$ & $* *$ \\
\hline \multirow[t]{4}{*}{ Spathiphyllum 'Sweet Chico' (15 cm) } & $\mathrm{H}$ & 280.5 & 132.5 & 9.0 & 56.4 \\
\hline & M & 272.3 & 124.3 & 8.6 & 52.9 \\
\hline & $\mathrm{L}$ & 264.2 & 116.2 & 8.1 & 49.4 \\
\hline & Significance & NS & NS & NS & NS \\
\hline
\end{tabular}

zThe following parameters were included: final biomass [initial and accumulated after 10 weeks (70 d) of growth under simulated conditions], biomass increase (shoot and root dry mass accumulated only during the 10 weeks under three $P P F$ levels), relative growth rate/day $\{[\ln ($ final mass $)-\ln ($ initial mass $)] \div 70 \mathrm{~d}\}$, and grams carbon sequestered during the 10 weeks [calculated by multiplying biomass increase by percent carbon (data from Table 3)]. PPF levels of 30,20 , or $10 \mu \mathrm{mol} \cdot \mathrm{m}^{-2} \cdot \mathrm{s}^{-1}$ are referred to as high $(\mathrm{H})$, medium $(\mathrm{M})$, or low $(\mathrm{L})$. Values are the mean per plant $(\mathrm{n}=6)$. Spathiphyllum size refers to a 4-inch pot $(10 \mathrm{~cm})$ and 6 -inch pot $(15 \mathrm{~cm})$.

${ }^{\mathrm{y}}$ Negative values represent loss of biomass.

${ }^{\mathrm{x}}$ Missing values: calculation was not performed as a result of negative numbers for biomass increase. NS, * **, and *** represent non-significant and significant linear effects of $P P F$ levels at $P=0.05,0.01$, and 0.001 , respectively.

$P P F=$ photosynthetic photon flux.
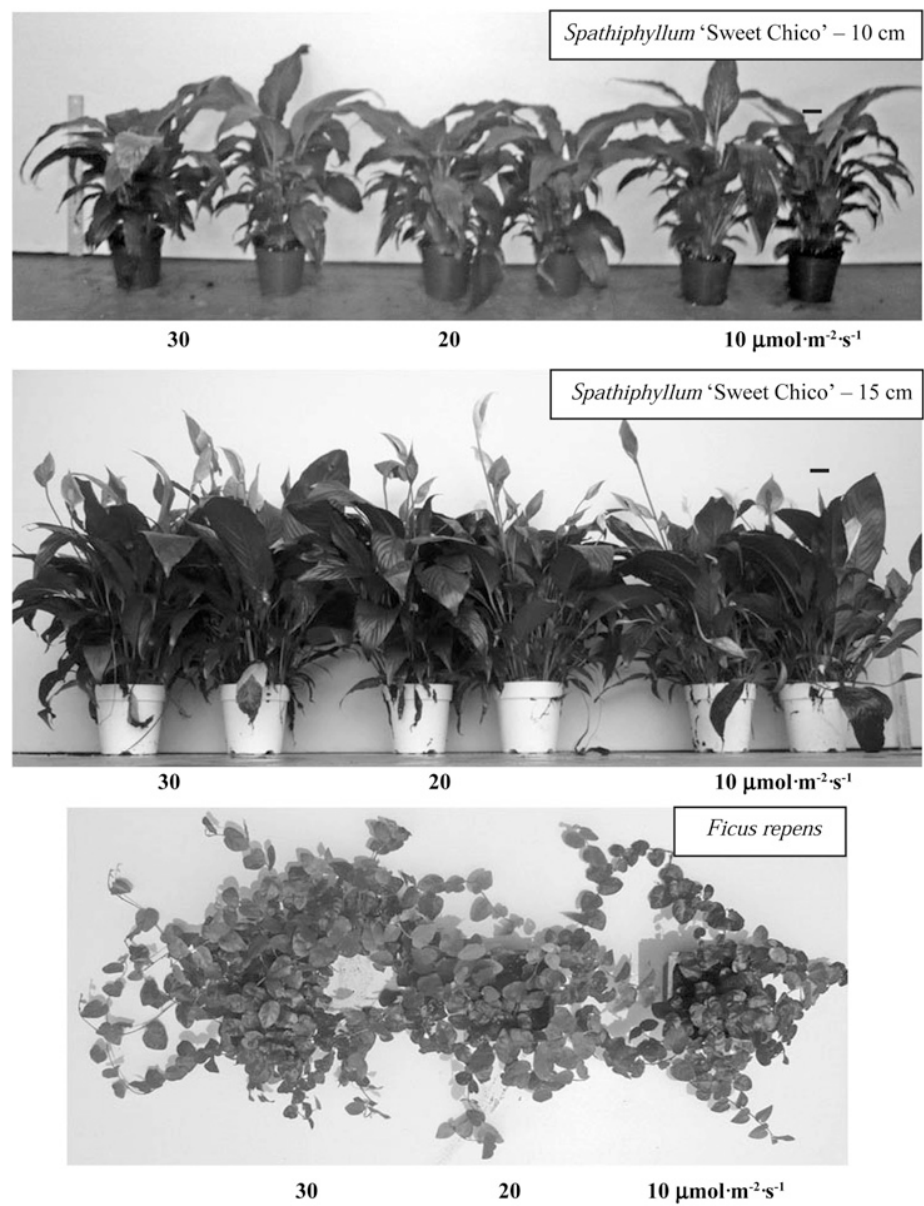

Fig. 2. Growth response of selected foliage species grown under three photosynthetic photon flux $(P P F)$ levels for a period of 10 weeks.

AG-6; Myron L Co., Carlsbad, CA). Medium fertility levels were found to be within appropriate levels on all testing dates (EC: 1.3 to $1.6 \mathrm{dS} \cdot \mathrm{m}^{-1}$; $\mathrm{pH}$ : 5.5 to 6.5 ) (Reed, 1996). appropriate ranges based on general recommendations for foliage plants (Mills and Jones, 1996).

Simulated environment. After acclimatization in the greenhouse, plants were placed in a growth chamber, where they were grown under one of three $P P F$ levels, low, medium, or high $P P F\left(\approx 10,20\right.$, and $30 \mu \mathrm{mol} \cdot \mathrm{m}^{-2} \cdot \mathrm{s}^{-1}$, respectively) and grown for a period of 10 weeks. The greenhouse was located on the University of Georgia Experiment Station in Griffin, GA. The medium and low PPF levels were achieved by placing plants under black shadecloth supported by small wood frames 30 (width) $\times 60$ (height) $\times 90$ (length) $\mathrm{cm}^{3}$. The high $P P F$ level was the ambient $P P F$ in the growth chamber. $P P F$ was provided by a mixture of metal halide and highpressure sodium lamps. $P P F$ measurements were made with a handheld quantum sensor (LI-190). Plants were grown under a 12-h photoperiod and $21{ }^{\circ} \mathrm{C}$ day/ $18{ }^{\circ} \mathrm{C}$ night air temperatures. They were irrigated weekly and fertilized biweekly (75 ppm nitrogen, $24 \mathrm{~N}-8 \mathrm{P}-16 \mathrm{~K})$.

Measurements. The following data were taken from plants subsequently placed under a simulated environment. A group of six plants per species served as the source for "initial" data such as number of leaves, shoot and root mass, carbon content, and leaf area. These plants had been subjected to acclimatization on the greenhouse bench as described previously. The initial data provided a reference point that allowed inferences on amount of growth (e.g., dry mass) that occurred under simulated conditions. Morphological data (i.e., number of leaves and leaf area) were taken on all plants (with the exception of number of leaves for Ficus benjamina, Spathiphyllum $15 \mathrm{~cm}$ size, and Ficus repens) after 10 weeks of growth under simulated interiorscape conditions. Whole plant leaf areas were taken with a leaf area meter (Li-3100 Leaf Area Meter; LI-COR, Lincoln, NE). Destructive sampling was achieved by removing growing media from roots and by physical separation of roots and shoots. Growing media was washed away before roots were placed in paper bags. For each plant, the roots and shoots were placed in separate bags and dried in a forced-air oven maintained at $80{ }^{\circ} \mathrm{C}$ for $7 \mathrm{~d}$. The dried shoot tissue samples were sent to the USDA-ARS Application Technology Research Unit (Toledo, $\mathrm{OH}$ ) for analysis of carbon concentration. Only shoots were analyzed because of the difficulty of completely separating the roots from the growing medium and all species (with the exception of C. oppenheimiana) accumulate more shoot than root mass. Relative growth rate (RGR) was calculated as $[\ln ($ final plant mass) $\ln$ (initial plant mass)] divided by $70 \mathrm{~d}$ and leaf area ratio (LAR) as area of new leaves divided by new shoot mass (Hunt, 1982). Carbon sequestration was calculated as new biomass (roots and shoots) times carbon concentration.

Statistical design and analysis. There were six replications of the $P P F$ treatments (individual shade structures) and two sub-replications 

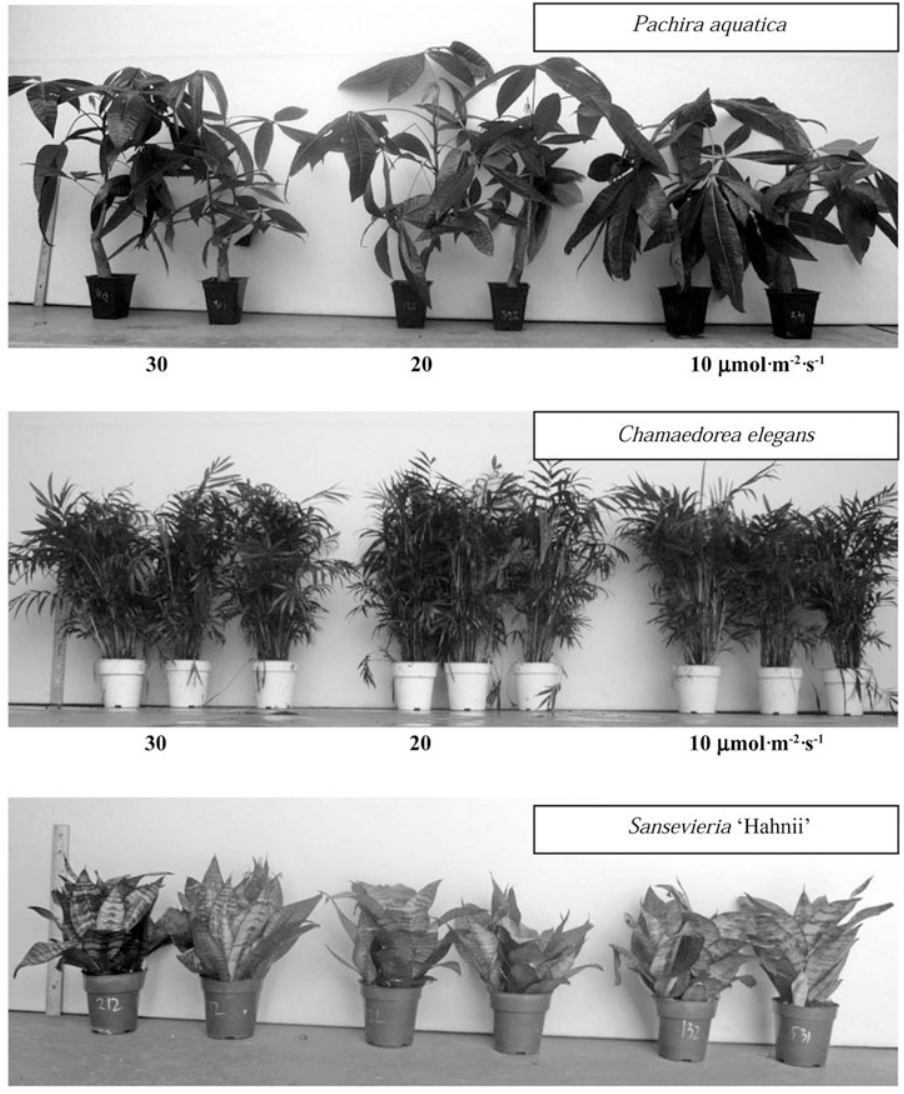

30

20

$10 \mu \mathrm{mol} \cdot \mathrm{m}^{-2} \cdot \mathrm{s}^{-1}$

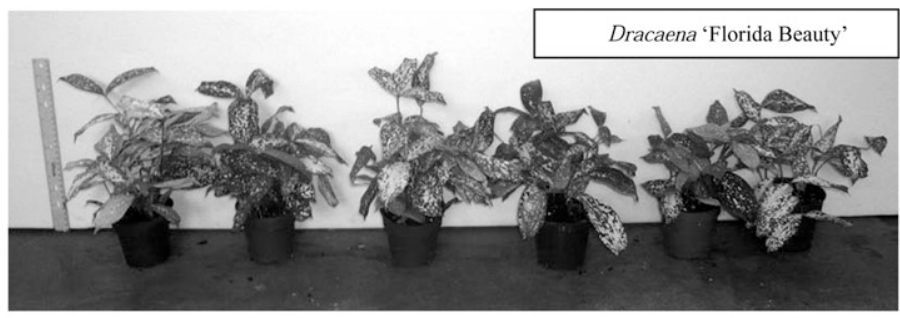

30

20

$10 \mu \mathrm{mol} \cdot \mathrm{m}^{-2} \cdot \mathrm{s}^{-1}$

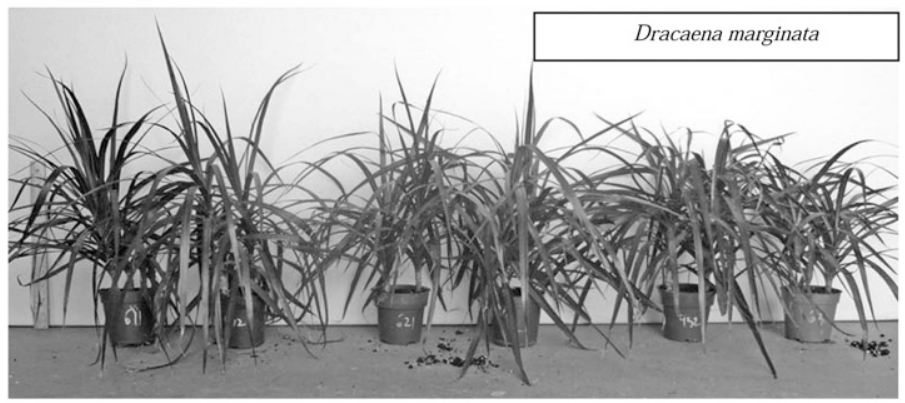

20

$10 \mu \mathrm{mol} \cdot \mathrm{m}^{-2} \cdot \mathrm{s}^{-1}$

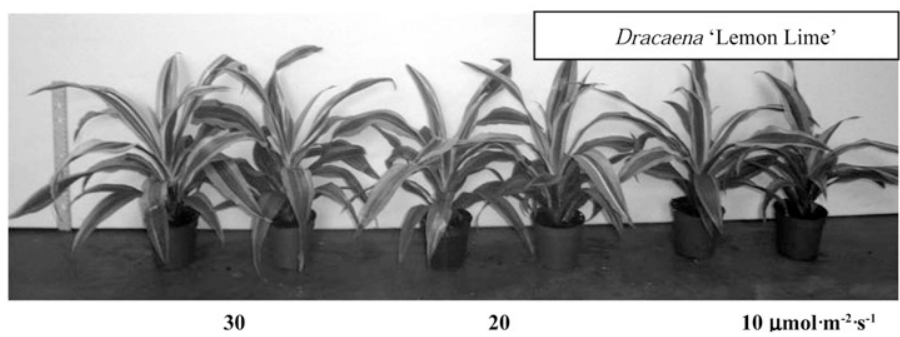

30 (two plants of each species per shade structure; a total of three species and six plants under each structure at one time). The three $P P F$ treatments within each replicate were placed within the space allocated to the replicate, and the six replicates were then placed in a randomized complete block design. Linear regression analysis of each morphological parameter was performed using SAS $^{\circledR}$ Enterprise Guide $\left.{ }^{(}\right)$Version 4.02 (SAS Institute, 2010) with PPF being the independent variable. Analyses were performed separately for each individual species.

Photosynthesis. Photosynthesis PPF response curves were measured before plants were placed under simulated interiorscape conditions but after acclimatization had been completed. A leaf was placed in a cuvette of the leaf photosynthesis system (CIRAS-1; PP Systems, Amesbury, MA) and exposed to progressively higher $P P F(\approx 0,10,20,30,40$, $50,75,100,250,500,750,1000,1500$, and $\left.2000 \mu \mathrm{mol} \cdot \mathrm{m}^{-2} \cdot \mathrm{s}^{-1}\right)$. Net photosynthesis $\left(\mathrm{P}_{\mathrm{n}}\right)$ was measured on the most recently matured leaf, midway between the midrib and leaf margin, and midway between the petiole and leaf tip. Dark respiration $\left(\mathrm{R}_{\mathrm{d}}\right)$, maximum quantum yield (the slope of the $P P F$ response curve at a $P P F$ of $\left.0 \mu \mathrm{mol} \cdot \mathrm{m}^{-2} \cdot \mathrm{s}^{-1}\right)$, and lightsaturated gross photosynthesis $\left(\mathrm{P}_{\text {gmax }}\right)$ were estimated from:

$\mathrm{P}_{\mathrm{n}}=\mathrm{P}_{\text {gmax }}\left[1-\mathrm{e}^{(- \text {quantum yield })(\mathrm{PPF}) / \text { Pgmax }}\right]-\mathrm{R}_{\mathrm{d}}$

The light compensation point was determined by solving this equation for the $P P F$ at which $\mathrm{P}_{\mathrm{n}}=0 \mu \mathrm{mol} \cdot \mathrm{m}^{-2} \cdot \mathrm{s}^{-1}$. Light-saturated $\mathrm{P}_{\mathrm{n}}$ was calculated as $\mathrm{P}_{\text {gmax }}-\mathrm{R}_{\mathrm{d}}$ (Burton et al., 2007).

\section{In situ environment}

The in situ environment was located in a public office building located at Galleria 200, Cobb Parkway, Atlanta, GA, and managed by Foliage Design Systems, Inc. The size of the interiorscape planting was $\approx 95 \mathrm{~m}^{2}$ and consisted of in-ground planters and individual plants in containers. Carbon gain of the plants in situ was assessed by collecting clippings and senesced foliage for a period of 12 months. Because the interiorscape was managed with the goal to maintain a stable plant size, senesced leaves and shoot clippings (stems with attached foliage) could be used as a proxy for plant growth. Each plant was assigned to a section within the interiorscape complete with $P P F$-level information taken at the plant canopy level. Some sections contained multiple species, whereas other sections contained a single species; for example, six plants of Brassaia in 18.9-L pots comprised a section (Fig. 1, Section 4), whereas a single 4.6-m Ficus benjamina planted with an underplanting of Scindapsus comprised a different section (Fig. 1, Section 1). The majority of plants had been maintained for a minimum of 5 years and some as long as 7 years. Senesced foliage and stem and foliar clippings from each species were collected monthly and placed in paper bags with 
information on species and location. The senesced foliage and shoot clippings were removed by a commercial interiorscape technician according to a regular schedule within the maintenance contract. Collected plant tissue was then brought in a laboratory for further processing. The tissue was dried in a forced-air oven maintained at $80^{\circ} \mathrm{C}$ for $7 \mathrm{~d}$. Subsequently, dry mass of the plant tissue was measured. If a section contained multiple plants of the same species, senesced foliage and shoot clippings from all plants were combined. At the end of the 12-month period, data were combined by location for each species.

\section{Results and Discussion}

\section{Simulated environment}

Biomass and carbon accumulation. With the exception of S. trifasciata 'Hahnii' Dracaena 'Janet Craig', Dracaena 'Lemon Lime', and Dracaena marginata, all species showed positive dry mass accumulation under all three $P P F$ levels (Table 1; Fig. 2). There was a positive correlation between $P P F$ and biomass increase for most species, even those that had a net decrease in biomass at some or all $P P F$ levels, indicating increasing growth at higher $P P F$. Relative growth rate and carbon sequestration exhibited similar correlations with $P P F$ (Table 1). For the two species represented by different size and age (Spathiphyllum 'Sweet Chico' and Ficus benjamina), larger and more mature plants tended to accumulate more mass and carbon than smaller plants. More mature $S$. 'Sweet Chico' tended to have a higher RGR than immature plants, whereas smaller $F$. benjamina tended to have a higher RGR than larger plants. Among plants in $10-\mathrm{cm}$ pots, Pachira had the highest dry mass accumulation (33.1 g) and the highest RGR (21.2 $\left.\mathrm{mg} \cdot \mathrm{g}^{-1} \cdot \mathrm{d}^{-1}\right)$.

Sansevieria and $D$. 'Janet Craig' did not exhibit positive carbon accumulation at any $P P F$ level. After 10 weeks under simulated conditions, these plants had lost some of their initial biomass through respiration (Table 1). Sansevieria's case was interesting because of the genus' inherent slow growth and very low photosynthetic rates. The plants lost the most reserves of all species in the 10 -week period. However, this behavior may not have continued; it is plausible that if the plants were grown for a longer duration, they might have acclimated to the simulated interiorscape conditions and eventually shown positive carbon gains.

Generally, $P P F$ levels in interiorscape settings are suboptimal for plant growth, even for many shade-adapted species (Conover and Poole, 1981). PPF has been shown to affect dry mass accumulation differently in sun vs. shade plants (Larcher, 2003). Both types of species have been shown to exhibit a quadratic response to $P P F$ with growth increasing as $P P F$ increases to a $P P F$ saturation level, then a plateau, followed by a decrease in growth at superoptimal $P P F$. However, this response curve is shifted toward the low $P P F$ range in the case of shade-obligate

Table 2. Growth and morphological characteristics of foliage species and cultivars as affected by $P P F$ level under simulated conditions. ${ }^{\mathrm{z}}$

\begin{tabular}{|c|c|c|c|c|c|c|}
\hline Species & $\begin{array}{c}P P F \\
\left(\mu \mathrm{mol} \cdot \mathrm{m}^{-2} \cdot \mathrm{s}^{-1}\right)\end{array}$ & $\begin{array}{l}\text { Shoot:root } \\
\text { ratio }\end{array}$ & $\begin{array}{c}\text { Shoot } \\
\text { mass } \\
(\mathrm{g})\end{array}$ & $\begin{array}{c}\text { Root } \\
\text { mass } \\
(\mathrm{g})\end{array}$ & $\begin{array}{l}\text { Leaf } \\
\text { area } \\
\left(\mathrm{cm}^{2}\right)\end{array}$ & $\begin{array}{c}\text { Leaf } \\
\text { area ratio } \\
\left(\mathrm{cm}^{-2} \cdot \mathrm{g}\right)\end{array}$ \\
\hline \multirow[t]{4}{*}{ Aglaonema spp. } & $\mathrm{H}$ & 0.7 & 13.1 & 12.5 & 501 & 41.9 \\
\hline & M & 0.6 & 10.1 & 12.5 & 510 & 51.1 \\
\hline & $\mathrm{L}$ & 0.9 & 9.7 & 5.0 & 328 & 33.6 \\
\hline & Significance & NS & $*$ & $*$ & $*$ & NS \\
\hline \multirow[t]{4}{*}{ Chamaedorea elegans } & $\mathrm{H}$ & 2.6 & 6.7 & 2.9 & 487 & 68.2 \\
\hline & M & 2.3 & 4.2 & 2.1 & 225 & 50.4 \\
\hline & $\mathrm{L}$ & 2.1 & 2.3 & 2.2 & 198 & 73.1 \\
\hline & Significance & $*$ & $* *$ & $*$ & $*$ & NS \\
\hline \multirow[t]{4}{*}{ Ctenanthe oppenheimiana } & $\mathrm{H}$ & 0.5 & 5.6 & 10.7 & 803 & 439 \\
\hline & M & 0.6 & 6.0 & 10.1 & 974 & 198 \\
\hline & $\mathrm{L}$ & 0.4 & 1.8 & 8.5 & 370 & 169 \\
\hline & Significance & NS & $*$ & $*$ & $*$ & $*$ \\
\hline \multirow[t]{4}{*}{ Dizygotheca elegantissima } & $\mathrm{H}$ & 4.2 & 3.5 & $-0.7^{z}$ & 312 & 97.7 \\
\hline & M & 3.4 & 2.1 & -1.7 & 145 & 123 \\
\hline & $\mathrm{L}$ & 4.5 & 1.1 & -0.1 & 241 & 294 \\
\hline & Significance & NS & $* *$ & NS & NS & NS \\
\hline \multirow[t]{4}{*}{ Dracaena godseffiana 'Florida Beauty' } & $\mathrm{H}$ & 1.3 & 2.7 & 2.8 & 472 & 165 \\
\hline & M & 1.5 & 3.0 & 2.5 & 447 & 162 \\
\hline & $\mathrm{L}$ & 1.5 & 1.2 & 1.1 & 156 & 110 \\
\hline & Significance & NS & $* *$ & $*$ & NS & NS \\
\hline \multirow[t]{4}{*}{ Dracaena deremensis 'Lemon Lime' } & $\mathrm{H}$ & 3.4 & 2.4 & -2.0 & 307 & 151 \\
\hline & M & 4.1 & 2.0 & -2.7 & 446 & 259 \\
\hline & $\mathrm{L}$ & 4.8 & 1.3 & -3.1 & 224 & 167 \\
\hline & Significance & NS & NS & $*$ & NS & NS \\
\hline \multirow[t]{4}{*}{ Dracaena deremensis 'Janet Craig' } & $\mathrm{H}$ & 5.5 & 4.1 & -4.7 & 467 & 123 \\
\hline & M & 6.2 & 3.6 & -5.1 & 434 & 134 \\
\hline & $\mathrm{L}$ & 6.6 & 1.8 & -5.3 & 279 & 169 \\
\hline & Significance & $*$ & NS & $*$ & NS & NS \\
\hline \multirow[t]{4}{*}{ Dracaena marginata } & $\mathrm{H}$ & 1.5 & 0.6 & 3.1 & -505 & $\underline{x}^{x}$ \\
\hline & M & 1.5 & 1.0 & 0.4 & -420 & - \\
\hline & $\mathrm{L}$ & 1.5 & -1.2 & 0.9 & -559 & - \\
\hline & Significance & NS & $*$ & $*$ & NS & - \\
\hline \multirow[t]{4}{*}{ Ficus benjamina immature } & $\mathrm{H}$ & 2.7 & 2.1 & 0.9 & 231 & 108 \\
\hline & M & 2.6 & 2.0 & 0.9 & 226 & 108 \\
\hline & $\mathrm{L}$ & 2.2 & 1.2 & 0.9 & 183 & 151 \\
\hline & Significance & NS & $*$ & NS & NS & $*$ \\
\hline \multirow[t]{4}{*}{ Ficus benjamina mature } & $\mathrm{H}$ & 3.7 & 3.4 & 1.3 & 257 & 74 \\
\hline & M & 3.5 & 2.4 & 1.0 & 312 & 128 \\
\hline & $\mathrm{L}$ & 3.9 & 1.5 & 0.5 & 216 & 145 \\
\hline & Significance & NS & $* *$ & $*$ & NS & $*$ \\
\hline \multirow[t]{4}{*}{ Ficus repens } & $\mathrm{H}$ & 1.7 & 1.1 & 0.2 & 403 & 383 \\
\hline & M & 1.0 & 0.6 & 0.8 & 256 & 146 \\
\hline & $\mathrm{L}$ & 0.6 & 0.1 & 1.1 & 172 & 106 \\
\hline & Significance & $* * *$ & $* *$ & $*$ & $* * *$ & $* *$ \\
\hline \multirow[t]{4}{*}{ Hedera helix } & $\mathrm{H}$ & 5.8 & 1.3 & 0.1 & 175 & 135 \\
\hline & M & 4.5 & 1.2 & 0.1 & 168 & 143 \\
\hline & $\mathrm{L}$ & 5.0 & 0.9 & 0.1 & 120 & 127 \\
\hline & Significance & NS & $*$ & NS & $*$ & $*$ \\
\hline \multirow[t]{4}{*}{ Pachira aquatica } & $\mathrm{H}$ & 3.9 & 27.4 & 5.7 & 934 & 34.8 \\
\hline & M & 2.4 & 18.9 & 6.0 & 737 & 46.7 \\
\hline & $\mathrm{L}$ & 1.7 & 12.7 & 5.4 & 607 & 66.0 \\
\hline & Significance & $* *$ & $* *$ & NS & $*$ & $*$ \\
\hline \multirow[t]{4}{*}{ Philodendron scandens } & $\mathrm{H}$ & 3.0 & 2.3 & 1.0 & 268 & 98.0 \\
\hline & M & 2.6 & 1.4 & 0.7 & 182 & 125 \\
\hline & $\mathrm{L}$ & 2.6 & 0.9 & 0.9 & 232 & 164 \\
\hline & Significance & NS & $*$ & NS & NS & NS \\
\hline \multirow[t]{4}{*}{ Sansevieria trifasciata 'Hahnii' } & $\mathrm{H}$ & 16.3 & 2.9 & -6.2 & 334 & - \\
\hline & M & 13.0 & -0.1 & -6.2 & 23.8 & - \\
\hline & $\mathrm{L}$ & 13.8 & -2.7 & -6.4 & -44.2 & - \\
\hline & Significance & NS & $*$ & NS & $* * *$ & \\
\hline
\end{tabular}

(Continued on next page)

plants and the high $P P F$ range in the case of sun plants. Depending on $P P F$ requirements of the species in question, extremely high and low PPF are likely to cause reductions in growth as a result of inhibition of photosynthesis at either extreme (Larcher, 2003). This behavior has been documented in sun plants such as Musa (Israeli et al., 1995) and Pisum sativum L. (Akhter et al., 2009) and shade-obligate Dracaena sanderana hort Sander ex. Mast. (Vladimirova et al., $1997)$. In the latter study, moderate shading $(63 \%$ or $80 \%$ shade, $\approx 740$ and 400 $\mu \mathrm{mol} \cdot \mathrm{m}^{-2} \cdot \mathrm{s}^{-1}$, respectively) allowed for the 
Table 2. (Continued) Growth and morphological characteristics of foliage species and cultivars as affected by $P P F$ level under simulated conditions. ${ }^{z}$

\begin{tabular}{|c|c|c|c|c|c|c|}
\hline Species & $\begin{array}{c}P P F \\
\left(\mu \mathrm{mol} \cdot \mathrm{m}^{-2} \cdot \mathrm{s}^{-1}\right)\end{array}$ & $\begin{array}{c}\text { Shoot:root } \\
\text { ratio }\end{array}$ & $\begin{array}{l}\text { Shoot } \\
\text { mass } \\
(\mathrm{g})\end{array}$ & $\begin{array}{c}\text { Root } \\
\text { mass } \\
(\mathrm{g})\end{array}$ & $\begin{array}{c}\text { Leaf } \\
\text { area } \\
\left(\mathrm{cm}^{2}\right)\end{array}$ & $\begin{array}{c}\text { Leaf } \\
\text { area ratio } \\
\left(\mathrm{cm}^{-2} \cdot \mathrm{g}\right)\end{array}$ \\
\hline \multirow{4}{*}{ Scindapsus aureus } & $\mathrm{H}$ & 1.6 & 4.7 & 2.7 & 380 & 87.0 \\
\hline & M & 2.1 & 3.4 & 1.7 & 375 & 110 \\
\hline & $\mathrm{L}$ & 2.0 & 2.6 & 2.0 & 324 & 130 \\
\hline & Significance & NS & $*$ & NS & $* *$ & $*$ \\
\hline \multirow[t]{4}{*}{ Spathiphyllum 'Sweet Chico' $(10 \mathrm{~cm})$} & $\mathrm{H}$ & 1.1 & 2.2 & 3.6 & 1014 & 460 \\
\hline & M & 1.4 & 1.6 & 1.0 & 773 & 485 \\
\hline & $\mathrm{L}$ & 1.5 & 1.5 & 0.9 & 813 & 541 \\
\hline & Significance & $* *$ & NS & $*$ & NS & $*$ \\
\hline \multirow[t]{4}{*}{ Spathiphyllum 'Sweet Chico' $(15 \mathrm{~cm})$} & $\mathrm{H}$ & 0.2 & $-7.1^{y}$ & 139.3 & 1319 & 一 \\
\hline & M & 0.2 & -8.3 & 132.4 & 969 & - \\
\hline & $\mathrm{L}$ & 0.2 & -10.0 & 125.9 & 566 & - \\
\hline & Significance & NS & $*$ & NS & $*$ & - \\
\hline
\end{tabular}

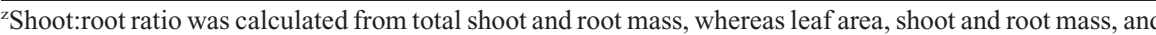
leaf area ratio are estimates of the new growth during the period that the plants were in the growth chamber. $P P F$ levels of 30,20 , or $10 \mu \mathrm{mol} \cdot \mathrm{m}^{-2} \cdot \mathrm{s}^{-1}$ are referred to as to as high $(\mathrm{H})$, medium $(\mathrm{M})$, or low (L). Values are the mean per plant $(\mathrm{n}=6)$.

${ }^{y}$ Negative values represent loss of dry mass.

${ }^{x}$ Missing values: calculation was not performed because leaf area and/or shoot dry mass decreased during the study.

NS, *, **, and *** represent non-significant and significant linear effects of $P P F$ levels at $P=0.05,0.01$, and 0.001 , respectively.

$P P F=$ photosynthetic photon flux.

Table 3. Shoot tissue carbon concentration for various foliage species as affected by $P P F$ (arranged from highest to lowest average values for all three $P P F$ levels). ${ }^{z}$

\begin{tabular}{|c|c|c|c|c|}
\hline \multirow[b]{2}{*}{ Species } & \multicolumn{4}{|c|}{ Percent carbon } \\
\hline & $30 \mu \mathrm{mol} \cdot \mathrm{m}^{-2} \cdot \mathrm{s}^{-1}$ & $20 \mu \mathrm{mol} \cdot \mathrm{m}^{-2} \cdot \mathrm{s}^{-1}$ & $10 \mu \mathrm{mol} \cdot \mathrm{m}^{-2} \cdot \mathrm{s}^{-1}$ & Significance \\
\hline$\overline{F . ~ b e n j a m i n a ~ m a t u r e ~}$ & 43.82 & 43.25 & 43.09 & NS \\
\hline H. helix & 42.26 & 43.45 & 43.30 & NS \\
\hline F. benjamina immature & 43.38 & 42.56 & 43.26 & NS \\
\hline D. elegantissima & 44.56 & 42.08 & 42.33 & $*$ \\
\hline Spathiphyllum 'Sweet Chico' & 42.83 & 42.55 & 42.21 & NS \\
\hline C. elegans & 42.14 & 41.73 & 42.34 & NS \\
\hline P. aquatica & 41.78 & 41.79 & 41.47 & NS \\
\hline Dracaena 'Florida Beauty' & 41.34 & 41.16 & 41.17 & NS \\
\hline C. oppenheimiana & 41.11 & 40.79 & 40.95 & NS \\
\hline D. 'Janet Craig' & 41.13 & 41.04 & 40.60 & NS \\
\hline D. marginata & 41.13 & 41.15 & 40.40 & NS \\
\hline D. 'Lemon Lime' & 40.24 & 39.92 & 41.15 & NS \\
\hline F. repens & 40.38 & 40.22 & 40.11 & NS \\
\hline P. scandens & 40.73 & 39.50 & 40.45 & NS \\
\hline Aglaonema spp. & 39.68 & 39.91 & 40.37 & $*$ \\
\hline S. aureus & 39.21 & 39.53 & 37.25 & NS \\
\hline Sansevieria 'Hahnii' & 38.48 & 38.02 & 37.69 & NS \\
\hline
\end{tabular}

${ }^{\mathrm{z}}$ Values are the mean per plant $(\mathrm{n}=2)$.

NS and * represent non-significant and significant linear effects of $P P F$ at $P=0.05$.

$P P F=$ photosynthetic photon flux.

greatest accumulation of dry matter in roots and shoots, whereas the highest (46\% shade, $\left.1080 \mu \mathrm{mol} \cdot \mathrm{m}^{-2} \cdot \mathrm{s}^{-1}\right)$ and lowest $P P F$ levels $\left(92 \%\right.$ shade, $\left.160 \mu \mathrm{mol} \cdot \mathrm{m}^{-2} \cdot \mathrm{s}^{-1}\right)$ resulted in reductions in dry matter accumulation. Another shade-obligate species, Geogenanthus undatus C. Koch \& Linden, exhibited 30\% higher total biomass when grown under 130 compared with $50 \mu \mathrm{mol} \cdot \mathrm{m}^{-2} \cdot \mathrm{s}^{-1}$ (Burton et al., 2007). Because of the low PPF levels in the growth chambers, we expected growth of all species to increase with increasing $P P F$ levels and this was confirmed by our findings (Tables 1 and 2).

Carbon concentration. Shoot carbon concentration (Table 3 ) ranged from $37.2 \%$ to $44.6 \%$ and tended to be lower in herbaceous species (e.g., S. aureus, $38 \%$ of dry mass) compared with woody ones (e.g., F. benjamina, was significant in Aglaonema, C. elegans, C. oppenheimiana, D. godseffiana 'Florida Beauty', $D$. deremensis 'Lemon Lime', $D$. deremensis 'Janet Craig', D. marginata, $F$. benjamina mature, F. repens, and Spathiphyllum 'Sweet Chico' in $15-\mathrm{cm}$ pots. With respect to shoot-to-root ratio, plants fell into one of three groups: species that increased their shoot-to-root ratio with increased $P P F$ (significant in C. elegans, $F$. repens, and $P$. aquatica; non-significant in $C$. oppenheimiana, $F$. benjamina immature, $H$. helix, $P$. scandens, and S. trifasciata 'Hahnii'), species that lowered their shoot-to-root ratio with increased PPF (significant in Spathiphyllum 'Sweet Chico' in 10-cm pots; non-significant in Aglaonema, D. elegantissima, D. godseffiana 'Florida Beauty', $D$. deremensis 'Lemon Lime', $D$. deremensis 'Janet Craig', $F$. benjamina mature, and $S$. aureus), and species in which shoot-to-root ratio did not change $(D$. marginata and Spathiphyllum 'Sweet Chico' in 15-cm pots).

With respect to LAR, species fell into one of two groups: species that increased their LAR with increased $P P F$ (significant in $C$. oppenheimiana, F. repens, and $H$. helix; nonsignificant in Aglaonema and D. godseffiana 'Florida Beauty') and species that lowered their LAR (significant in $F$. benjamina immature and mature, P. aquatica, $S$. aureus, and $S$. 'Sweet Chico' in 10-cm pots; non-significant in C. elegans, D. elegantissima, D. deremensis 'Janet Craig', and P. scandens).

Light has been shown to change dry mass accumulation and partitioning in both sun and shade plants. Plants grown under low light generally allocate a larger fraction of their biomass to their shoots and leaves compared with plants grown under high light (Taiz and Zeiger, 2010). Leaf morphology also changes with plants grown under low light developing thinner leaves than plants grown under high light (Makino et al., 1997). However, eight genotypes of Pisum sativum L., a sun plant, behaved differently when grown under different light levels $(100 \%$ to $25 \%$ of full sun); four allocated more mass to the shoot, whereas the rest decreased their allocation to the shoot in response to decreasing light (Akhter et al., 2009), indicating that there is genotypic variation in responses to light, even within a single species. A tropical pioneer woody species, Croton urucurana Baill, had higher shoot dry weight and higher leaf area when grown under $30 \%$ of full sun compared with full sun (Alves de Alvarenga et al., 2003). Two tropical forest species, Warburgia ugandensis and Polyscias fulva, showed increased leaf area and higher leaf numbers when grown under $P P F$ levels of less than $42 \%$ of full sun compared with $65 \%$ of full sun (Kinyamario et al., 2008)

In the present study, some species exhibited significant responses to the three different $P P F$ levels, whereas others did not. This could be explained by differences in their inherent genotypical, physiological, morphological, and anatomical characteristics. Most plants used in interiorscapes are of tropical origin and can adapt to grow in low 
Table 4. Photosynthetic features of selected foliage species as determined from photosynthesis $-P P F$ response curves. ${ }^{2}$

\begin{tabular}{|c|c|c|c|c|c|}
\hline Species & $\begin{array}{c}\text { Dark respiration } \\
\left(\mu \mathrm{mol} \cdot \mathrm{m}^{-2} \cdot \mathrm{s}^{-1}\right)\end{array}$ & $\begin{array}{l}\text { Maximum net } \\
\text { photo synthesis } \\
\left(\mu \mathrm{mol} \cdot \mathrm{m}^{-2} \cdot \mathrm{s}^{-1}\right)\end{array}$ & $\begin{array}{l}\text { Maximum gross } \\
\text { photo synthesis } \\
\left(\mu \mathrm{mol} \cdot \mathrm{m}^{-2} \cdot \mathrm{s}^{-1}\right)\end{array}$ & $\begin{array}{l}\text { Maximum } \\
\text { quantum yield } \\
\left(\mathrm{mol} \cdot \mathrm{mol}^{-1}\right)\end{array}$ & $\begin{array}{c}\text { Light compensation } \\
\text { point } \\
\left(\mu \mathrm{mol} \cdot \mathrm{m}^{-2} \cdot \mathrm{s}^{-1}\right)\end{array}$ \\
\hline C. oppenheimiana & 0.80 & 6.80 & 7.60 & 0.058 & 15 \\
\hline F. benjamina & 0.46 & 4.83 & 5.29 & 0.022 & 22 \\
\hline H. helix & 0.55 & 7.07 & 7.62 & 0.069 & 8 \\
\hline P. scandens & 0.38 & 3.45 & 3.83 & 0.007 & 56 \\
\hline S. aureus & 0.60 & 5.49 & 6.09 & 0.015 & 41 \\
\hline F. repens & 0.83 & 3.51 & 4.34 & 0.012 & 78 \\
\hline
\end{tabular}

${ }^{\mathrm{z}}$ Values are the mean per plant $(\mathrm{n}=2$ to 4$)$.

$P P F=$ photosynthetic photon flux.

PPF environments (Conover and Poole, 1981). Some of these species are known to tolerate full sun (e.g., F. benjamina), whereas others are shade-obligate (e.g., Aglaonema).

From the present study conducted under simulated conditions, several general trends for plant behavior could be inferred for foliage species when placed under typical interiorscape light levels. For the initial 10week period, plants would grow, adding new and/or larger leaves. Depending on the species, this increase would come from stored reserves and/or photosynthesis. Sansevieria and Dracaena deremensis would tend to use up stored reserves, mostly from their roots and possibly add several new leaves. Dracaena marginata would exhibit positive biomass accumulation but lose leaves. This is possibly related to different strategies of coping with low $P P F$; species that defoliate with more ease (e.g., D. marginata) initially loose leaves, whereas species that do not defoliate (i.e., D. deremensis) spent their reserves to develop new leaves and increase leaf area. Most foliage species would increase their LAR as a means to acclimate to lower PPF levels.

Photosynthetic performance. We were able to collect photosynthesis $P P F$ response curves for only six of the species; photosynthetic rates of the other species were too low to be measured accurately. $\mathrm{P}_{\text {gmax }}$ ranged from $3.8 \mu \mathrm{mol} \cdot \mathrm{m}^{-2} \cdot \mathrm{s}^{-1}$ for $P$. scandens to 7.6 $\mu \mathrm{mol} \cdot \mathrm{m}^{-2} \cdot \mathrm{s}^{-1}$ for $C$. oppenheimiana and $H$. helix (Table 4; Fig. 3). Such $\mathrm{P}_{\text {gmax }}$ rates are comparable to those of shade-obligate species like Geogenanthus undatus 'Inca' and Smilacina racemosa $\left(\mathrm{P}_{\mathrm{gmax}}\right.$ of 3.4 and 3.9 $\mu \mathrm{mol} \cdot \mathrm{m}^{-2} \cdot \mathrm{s}^{-1}$, respectively) (Burton et al., 2007; Hull, 2002). The light compensation point ranged widely among species, from $8 \mu \mathrm{mol} \cdot \mathrm{m}^{-2} \cdot \mathrm{s}^{-1}$ for $H$. helix to $78 \mu \mathrm{mol} \cdot \mathrm{m}^{-2} \cdot \mathrm{s}^{-1}$ for $F$. repens. These light compensation points are generally higher than that reported for the shade-obligate Podophyllum peltatum (11 $\left.\mu \mathrm{mol} \cdot \mathrm{m}^{-2} \cdot \mathrm{s}^{-1}\right)$, Arisaema triphyllum $\left(5 \mu \mathrm{mol} \cdot \mathrm{m}^{-2} \cdot \mathrm{s}^{-1}\right)$, S. racemosa $\left(9 \mu \mathrm{mol} \cdot \mathrm{m}^{-2} \cdot \mathrm{s}^{-1}\right)$ (Hull, 2002), and G. undatus $\left(2.8 \mu \mathrm{mol} \cdot \mathrm{m}^{-2} \cdot \mathrm{s}^{-1}\right)$ (Burton et al., 2007) as well as those of six interiorscape species in the Araceae family (3.0 to $8.2 \mu \mathrm{mol} \cdot \mathrm{m}^{-2} \cdot \mathrm{s}^{-1}$ ) (Giorgioni and Neretti, 2010). The maximum quantum yield ranged from $0.007 \mathrm{~mol} \cdot \mathrm{mol}^{-1}$ for $P$. scandens to 0.069 $\mathrm{mol} \cdot \mathrm{mol}^{-1}$ for $H$. helix. This 10 -fold variation in maximum quantum yield is consistent with the finding the even within the Araceae family, there are large differences in maximum
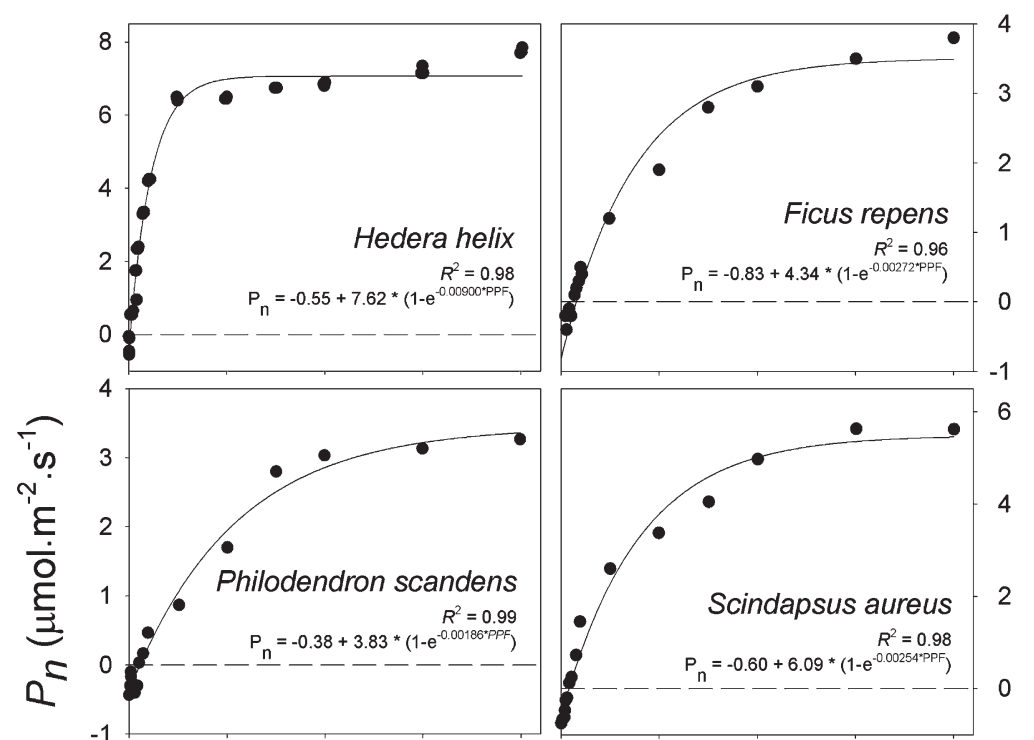

2

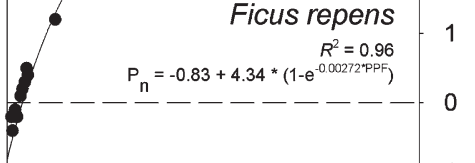

$-1$

2
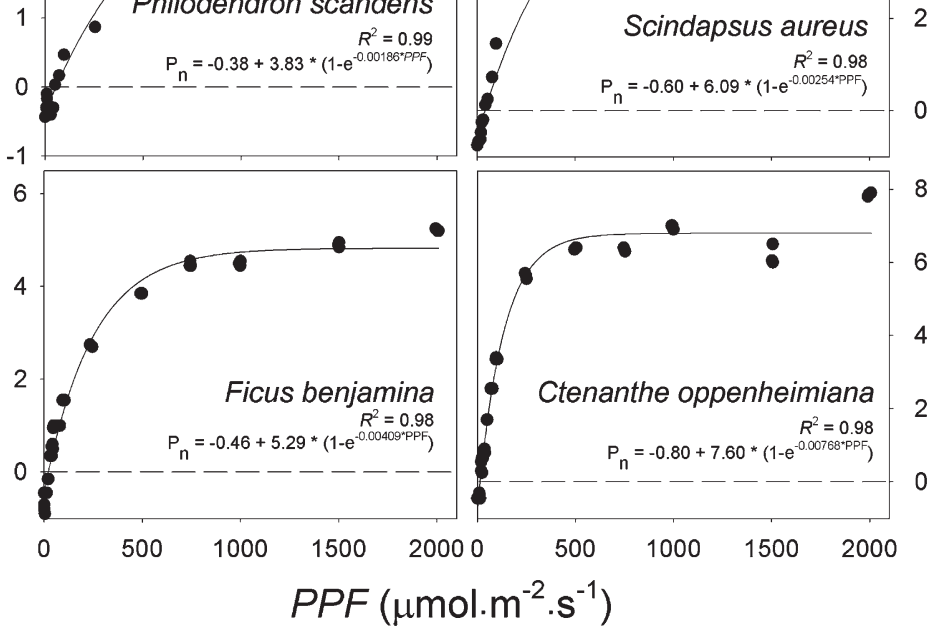

6

4

2

PPF $\left(\mu \mathrm{mol} \cdot \mathrm{m}^{-2} \cdot \mathrm{s}^{-1}\right)$

Fig. 3. Photosynthesis: photosynthetic photon flux $(P P F)$ response curves of selected foliage species. Data were collected on plants after they had been acclimated to low light levels in a greenhouse but before placing them in simulated interiorscapes.

quantum yield among species ( 0.0014 to 0.112 $\mathrm{mol} \cdot \mathrm{mol}^{-1}$ ) (Giorgioni and Neretti, 2010).

\section{In situ environment}

The total aboveground biomass accumulated by the plants in the interiorscape was $42,672 \mathrm{~g}$, of which $39,312 \mathrm{~g}(92 \%)$ was contributed by just a few woody plants (4.6$\mathrm{m}$ and 3.7-m F. benjamina, 3-m Ficus 'Alii', 1.2-m Podocarpus, and 2.4-m Dracaena reflexa) (Table 5). In general, within a particular species, the biomass that was removed reflected the location ( $P P F$ level) and size of container where the plant was growing; i.e., the amount of foliage and clippings collected from $F$. benjamina increased with increasing $P P F$ and container size, whereas that of
Podocarpus increased with increasing $P P F$. In practical terms, if the $P P F$ level was adequate and if space allowed, a plant would continue to accrue biomass until pruning/ repotting was necessary. The single Howea palm in the study, although showing only $1 \mathrm{~g}$ of clippings, had likely accumulated considerably more dry weight than recorded. However, because there was no necessity to trim the plant (and it had not outgrown its location), only a small amount of clippings was collected.

It is important to recognize that the senesced foliage and shoot clippings constitute only part of the biomass accumulation and growth of the interiorscape plants. Biomass was accrued in the new leaves, stems, and 
Table 5. Dry mass of senesced foliage and shoot clippings of plants collected from an $\approx 95-\mathrm{m}^{2}$ interiorscape. ${ }^{\mathrm{z}}$

\begin{tabular}{|c|c|c|c|}
\hline Species/size & $P P F\left(\mu \mathrm{mol} \cdot \mathrm{m}^{-2} \cdot \mathrm{s}^{-1}\right)$ & No. of plants & Dry mass $(\mathrm{g})$ \\
\hline $\begin{array}{l}\text { 4.6-m F. benjamina (planter size: } \\
1.2 \mathrm{~m} \mathrm{~W} \times 0.6 \mathrm{~m} \mathrm{H} \text { ) }\end{array}$ & 70 & 1 & 11,173 \\
\hline $\begin{array}{l}\text { 4.6-m } F \text {. benjamina (planter size: } \\
1.2 \mathrm{~m} \mathrm{~W} \times 0.6 \mathrm{~m} \mathrm{H} \text { ) }\end{array}$ & 50 & 1 & 9,207 \\
\hline $\begin{array}{l}\text { 3.7-m } F \text {. benjamina } \text { (planter size: } \\
0.6 \mathrm{~m} \mathrm{~W} \times 0.8 \mathrm{~m} \mathrm{H})\end{array}$ & 70 & 1 & 4,281 \\
\hline $\begin{array}{l}\text { 3.7-m } F \text {. benjamina (planter size: } \\
\quad 0.6 \mathrm{~m} \mathrm{~W} \times 0.8 \mathrm{~m} \mathrm{H} \text { ) }\end{array}$ & 40 & 1 & 2,964 \\
\hline 2.4-m Dracaena reflexa & 80 & 1 & 4,540 \\
\hline $\begin{array}{l}\text { 3-m Ficus 'Alii' (planter size: } \\
1.2 \mathrm{~m} \mathrm{~W} \times 0.6 \mathrm{~m} \mathrm{H})\end{array}$ & 50 & 3 & 6,195 \\
\hline $\begin{array}{l}\text { 1.2-m Podocarpus (planter size: } \\
0.9 \mathrm{~m} \mathrm{~W} \times 0.2 \mathrm{~m} \mathrm{H} \text { ) }\end{array}$ & 80 & 2 & 225 \\
\hline $\begin{array}{l}\text { 1.2-m Podocarpus (planter size: } \\
0.9 \mathrm{~m} \mathrm{~W} \times 0.2 \mathrm{~m} \mathrm{H} \text { ) }\end{array}$ & 80 & 2 & 197 \\
\hline $\begin{array}{l}\text { 1.2-m Podocarpus (planter size: } \\
0.9 \mathrm{~m} \mathrm{~W} \times 0.2 \mathrm{~m} \mathrm{H} \text { ) }\end{array}$ & 70 & 2 & 181 \\
\hline $\begin{array}{l}\text { 1.2-m Podocarpus (planter size: } \\
0.9 \mathrm{~m} \mathrm{~W} \times 0.2 \mathrm{~m} \mathrm{H} \text { ) }\end{array}$ & 60 & 2 & 150 \\
\hline $\begin{array}{l}\text { 1.2-m Podocarpus (planter size: } \\
0.9 \mathrm{~m} \mathrm{~W} \times 0.2 \mathrm{~m} \mathrm{H} \text { ) }\end{array}$ & 40 & 2 & 77 \\
\hline $\begin{array}{l}\text { 1.2-m Podocarpus (planter size: } \\
0.9 \mathrm{~m} \mathrm{~W} \times 0.2 \mathrm{~m} \mathrm{H} \text { ) }\end{array}$ & 40 & 2 & 72 \\
\hline Trichilla & 15 & 1 & 48 \\
\hline Howea fosteriana & 80 & 1 & 1 \\
\hline & & Woody plant total & 39,312 \\
\hline Brassaia (planter size 18.9 L) & 35 & 6 & 202 \\
\hline Brassaia (planter size 18.9 L) & 20 & 6 & 47 \\
\hline Dracaena 'Janet Craig' & 30 & 10 & 24 \\
\hline Aspidistra & 50 & 10 & 191 \\
\hline Aspidistra (8 months) & 4 & 5 & 40 \\
\hline Aspidistra (8 months) & 0.5 & 5 & 19 \\
\hline Aglaonema & 80 & 10 & 181 \\
\hline Aglaonema & 80 & 5 & 103 \\
\hline Aglaonema & 40 & 5 & 69 \\
\hline Aglaonema (8 months) & 10 & 6 & 60 \\
\hline Aglaonema (8 months) & 1 & 6 & 37 \\
\hline Zamioculcas & 80 & 5 & 7 \\
\hline $\begin{array}{l}\text { Scindapsus (planter size: } 1.2 \mathrm{~m} \mathrm{~W} \times \\
0.6 \mathrm{~m} \text { H underplanting } \\
\text { of } F . \text { benjamina) }\end{array}$ & 70 & 5 & 198 \\
\hline $\begin{array}{l}\text { Scindapsus (planter size: } 1.2 \mathrm{~m} \mathrm{~W} \times \\
0.6 \mathrm{~m} \text { H underplanting } \\
\text { of } F . \text { benjamina) }\end{array}$ & 50 & 5 & 153 \\
\hline $\begin{array}{l}\text { Scindapsus (planter size: } 0.6 \mathrm{~m} \mathrm{~W} \times \\
0.8 \mathrm{~m} \text { H underplanting } \\
\text { of } F . \text { benjamina) }\end{array}$ & 70 & 4 & 382 \\
\hline $\begin{array}{l}\text { Scindapsus (planter size: } 0.6 \mathrm{~m} \mathrm{~W} \times \\
0.8 \mathrm{~m} \text { H underplanting } \\
\text { of } F \text {. benjamina) }\end{array}$ & 40 & 4 & 141 \\
\hline $\begin{array}{l}\text { Scindapsus (planter size: } 0.9 \mathrm{~m} \mathrm{~W} \times \\
0.2 \mathrm{~m} \text { H underplanting } \\
\text { of Podocarpus) }\end{array}$ & 70 & 5 & 105 \\
\hline $\begin{array}{l}\text { Scindapsus (planter size: } 0.9 \mathrm{~m} \mathrm{~W} \times \\
0.2 \mathrm{~m} \mathrm{H} \text { underplanting } \\
\text { of Podocarpus) }\end{array}$ & 60 & 5 & 90 \\
\hline $\begin{array}{l}\text { Scindapsus (planter size: } 0.9 \mathrm{~m} \mathrm{~W} \times \\
0.2 \mathrm{~m} \text { H underplanting } \\
\text { of Podocarpus }\end{array}$ & 40 & 10 & 339 \\
\hline $\begin{array}{l}\text { Scindapsus (in-ground planter with } \\
\text { Dracaena 'Janet Craig') }\end{array}$ & 30 & 10 & 437 \\
\hline $\begin{array}{l}\text { Ficus repens (underplanting } \\
\text { of Podocarpus) }\end{array}$ & 80 & 20 & 290 \\
\hline $\begin{array}{l}\text { Ficus repens (underplanting } \\
\text { of Podocarpus) }\end{array}$ & 40 & 6 & 10 \\
\hline \multirow{2}{*}{$\begin{array}{l}\text { Hedera helix (whole plant'; planter size: } \\
1.2 \mathrm{~m} \mathrm{~W} \times 0.6 \mathrm{~m} \mathrm{H} \text { underplanting } \\
\text { of } F \text {. 'Alii') }\end{array}$} & 50 & 5 & 214 \\
\hline & & Total & 42,672 \\
\hline
\end{tabular}

${ }^{\mathrm{z}}$ Except where noted, values represent data from 12 months. The last column represents the total dry mass of all plants of that species in that location (as listed under No. of plants). Except where planter size listed, plants were in in-ground containers.

${ }^{\mathrm{y}}$ The entire plant was removed from the planting.

$P P F=$ photosynthetic photon flux; $\mathrm{W}=$ width; $\mathrm{H}=$ height. roots; however, those were not assessed. In general, most of the plants were located under sufficient light levels to allow growth to occur.

In terms of carbon, the interiorscape plants fixed $\approx 17,000 \mathrm{~g}$ (based on $40 \%$ of dry mass). The major part was attributed to the larger arboreal plants. Although photosynthetic measurements of plants in situ were attempted, photosynthetic rates were too low to be measured with the leaf photosynthesis system.

To put the data from this research in perspective, we must look at some practical considerations. For example, how does carbon fixed by the interiorscape plants equate to carbon released from fossil fuels? How does it compare with the amount of carbon dioxide exhaled by a single person? The approximate amount of carbon exhaled by a single human in $1 \mathrm{~d}$ is $\approx 300 \mathrm{~g}$ (Giorgioni and Neretti, 2010), whereas the carbon content of $1 \mathrm{~L}$ of gasoline is $640 \mathrm{~g}$ (EPA, 2011). In comparison, a single Spathiphyllum in a $15-\mathrm{cm}$ pot grown at a $P P F$ of $20 \mu \mathrm{mol} \cdot \mathrm{m}^{-2} \cdot \mathrm{s}^{-1}$ fixed $0.8 \mathrm{~g} \mathrm{C}$ per day, so it would take $\approx 400$ plants to offset a single human or 845 plants to offset a gasoline use of $1 \mathrm{~L} \cdot \mathrm{d}^{-1}$.

\section{Conclusions}

Carbon fixation in an interiorscape was dominated by a few large plants. Over time larger plants (which are generally woody species) accumulated significantly larger quantities of dry mass (and carbon) compared with smaller, herbaceous species. Although positive carbon gains were demonstrated both under simulated and in situ conditions, the reduction in ambient carbon dioxide levels by interiorscape plants is not likely to substantiate claims for a significant impact on indoor air quality. Interiorscape plants have been documented to remove volatile organic compounds (VOCs), and it is this aspect that should serve as a basis for the claim for improvement of indoor air quality. Carbon dioxide assimilation provides corollary information to the VOC removal and a more complete assessment of plants' benefits to the interiorscape environment.

\section{Literature Cited}

Akhter, N.M., M. Rahman, M. Hasannazzaman, and K. Nahar. 2009. Dry matter partitioning in Garden Pea (Pisum sativum L.) as influenced by different PPF levels. Acad. J. Plant Sci. 2:233-236.

Alves de Alvarenga, A., E. Castro, M. Lima, É. de Castro, and M.M. Magalhaes. 2003. Effects of different PPF levels on the initial growth and photosynthesis of Croton urucurana Baill. in southeastern Brazil. Rev. Árvore 27:53-57.

Bringslimark, T., T. Hartig, and G.G. Patil. 2007. Psychological benefits of indoor plants in workplaces: Putting experimental results into context. HortScience 42:581-587.

Burton, A., S.V. Pennisi, and M.W. van Iersel. 2007. Morphology and postharvest performance of Geogenanthus undatus C. Koch \& Linden 'Inca' following application of ancymidol or flurprimidol. HortScience 42:544-549.

Conover, C.A. and R.T. Poole. 1981. Environmental factors, p. 269-283. In: Joiner, J. (ed.). Foliage plant production. Prentice-Hall, Englewood Cliffs, NJ. 
EPA. 2011. Emission facts: Average carbon dioxide emissions resulting from gasoline and diesel fuel. 17 Oct. 2011. <http://www.epa.gov/ otaq/climate/420f05001.htm\#carbo>.

Giorgioni, M.E. and U. Neretti. 2010. Effects of artificial $P P F$ intensity and ambient $\mathrm{CO}_{2}$ level on photosynthesis of Araceae species commonly used for interior landscaping. Acta Hort. 881:607-702.

Hull, J.C. 2002. Photosynthetic induction dynamics to sunflecks of four deciduous understory herbs with different phonologies. Intl. J. Plant Sci. 163:913-924.

Hunt, R. 1982. Plant growth curves. The functional analysis to plant growth analysis. University Park Press, Baltimore, MD.

Israeli, Y., Z. Plaut, and A. Schwartz. 1995. Effect of shade on banana morphology, growth and production. Sci. Hort. 62:45-56.

Kinyamario, J.I., T.P. Wang'ombe, and J. Wanyoundu. 2008. Growth characteristics of two tropical forest species Warburgia ugandensis and Polyscias fulva seedlings grown under contrasting $P P F$ conditions. Afr. J. Envir. Sci. Technol. 2:15-21.

Larcher, W. 2003. Physiological plant ecology. 4th Ed. Springer-Verlag, New York, NY.

Lohr, V.I., C.H. Pearson-Mims, and G.K. Goodwin. 1996. Interior plants may improve worker productivity and reduce stress in a windowless environment. J. Environ. Hort. 14:97-100.

Makino, A., T. Sato, H. Nakano, and T. Mae. 1997. Leaf photosynthesis, plant growth and nitrogen allocation in rice under different $P P F$ s. Planta 203:390-398.

Manaker, G. 1981. Light, p. 32-76. In: Interior plantscapes: Installation, maintenance and management. 3rd Ed. Prentice Hall, Upper Saddle River, NJ.

Mills, H.A. and J.B. Jones, Jr. 1996. Plant analysis handbook II. MicroMacro Publishing, Athens, GA.

Reed, D.W. 1996. A grower's guide to water, media, and nutrition for greenhouse crops. Ball, Batavia, IL.

SAS Institute. 2010. SAS ${ }^{\circledR}$ Enterprise Guide ${ }^{\circledR}$. SAS Institute, Cary, NC.
Taiz, L. and E. Zeiger. 2010. Plant physiology. 5th Ed. Sinauer Associates, Inc., Sunderland, MA. USGBC. 2011. U.S. Green Building Council. 1 Sept. 2011. <http://www.usgbc.org>.

van Iersel, M.W. and B. Bugbee. 2000. A semicontinuous, multi-chamber crop $\mathrm{CO}_{2}$-exchange system: Design, calibration, and data interpretation. J. Amer. Soc. Hort. Sci. 125:8692.

Vladimirova, S.V., D.B. McConnell, M.E. Kane, and R.W. Henley. 1997. Morphological plasticity of Dracaena sanderiana 'Ribbon' in response to four PPF intensities. HortScience 32:10491052.

Yang, D.S., S.V. Pennisi, K.C. Son, and S.J. Kays. 2009. Screening indoor plants for volatile organic pollutant removal efficiency. HortScience 44:1377-1381.

Yeager, T., C. Gilliam, T. Bilderback, D. Fare, A. Niemiera, and K. Tilt. 1997. Best management practices: Guide for producing containergrown plants. Southern Nurserymen's Association, Marietta, GA. 